\title{
Effect of Chitosan and Clove Oil on Physical and Chemical Properties of Red Roomy Grapes During Cold Storage
}

A- Effect of Chitosan and Clove Oil on Weight Loss and Decay Percentages

\author{
Elmahdy, T.K. ${ }^{1}$; M.M. El-Akad ${ }^{1}$; E.M. Abd El-Zaher ${ }^{2}$ and \\ Al-Zahraa Abd-Ellah Mahmoud ${ }^{2}$
}

${ }^{1}$ Department of Pomology, Faculty of Agriculture, Assiut University, Assiut, Egypt.

${ }^{2}$ Department of Pomology, Faculty of Agriculture, New valley, Egypt.

Received on: $11 / 4 / 2018$

Accepted for publication on: 23/4/2018

\begin{abstract}
This work was carried out during two successive seasons 2015 and 2016 to study the effect of Red Roomy grapes coating with chitosan (2\%) and clove oil $(3 \%)$ on weight loss and decay percentages during cold storage. The obtained result showed that fruit weight $\operatorname{loss}(\%)$ and decay( $(\%)$ significantly increased by all treatments with advancing the storage duration and reached its maximum values at the end of storage period. Moreover at the end of storage period the highest values of weight loss (\%) and decay (\%) were recorded in uncoated grapes (control) as compared with both chitosan and clove oil coating during both experimental seasons. In addition the lowest values of weight loss and decay $\%$ were found in the grapes coated with chitosan during the first season (2015), while the coated grapes with clove oil had the lowest percentages of weight loss and decay during the second season (2016).
\end{abstract}

Keywords: Storage, postharvest, chitosan, clove oil, weight loss, decay, grapes

\section{Introduction:}

Grape (Vitus vinifera, L) is considered as one of the most popular and favorite fruits crops in the world, for being of a good flavor and high nutritional value. It considered an important source of antioxidants such as vitamins, phenols, flavonoid, anthocyanin and contributing to the health benefits (Anastasiadi et al. 2010).

About $35-40 \%$ fruits and vegetable are lost during post-harvest condition (Kumar and Bhatnagar 2014). Post-harvest loss of fruits is serious problem due to rapid deterioration during harvesting, transportation, handling and storage condition especially in tropical region (Gatto et al. 2011) and (Terry and Joyce 2004).

Edible coatings are used on vegetable and fruits to improve ap- pearance, modifying atmosphere around fruit's surface to reduce fruit respiration rate of fruit and improve the environmental condition like humidity and temperature (Baldwin et al. 1995). These coating materials providing a semi permeable berries for enhancing carbon dioxide rates and reducing oxygen rates and therefor reducing respiration retard the ripening, reducing decay and water loss, decrement the oxidation reaction rates and metabolic activities, especially transpiration and respiration. So, coating fruits becomes more resistance to pathogens and promoting their marketing and storage ability (Petracek et al. 1998), (Park 1999) and (Chitarra and Chitarra 2005).

Chitosan is one of the most common natural polymers that can be obtained from various species, par- 
ticularly from the exoskeletons of crustaceans. It is also found in cuticles of insects and in the cell walls of fungi and some algae (Sandford and Hutching 1986 and EPA1995). It is a polysaccharide derived from a low acetyl from of chitin, mainly composed of glucosamine and $\mathrm{N}$ acetylglucoseamine.

Chitosan- based coating are considered the best edible and biologically safe preservative coating for different types of fruits, with functional advantages, such as slower respiration, extending of storage period and shelf life of fruits, firmness retention and controlling microbial pathogens (Du et al.1997). (Shiri et al. 2013) found that "shahroudi" grape cv. coated with chitosan and then stored at $0^{\circ} \mathrm{C}$ for 60 days showed less weight loss $\%$, decay $\%$, browning, shattering with increasing acidity percentage.

In the recent years, environmentally friendly essential oils (EOS) have been extensively studied as a natural food and fruits preservatives due to their broad antimicrobial activities (Davidson et al. 2013).

Clove oil has been proven to be very effective against different fungal diseases and various pathogens and therefore to maintenance the fruit quality during storage. Coated papaya fruits with clove oil combined with Gum ghatti showed a reduction of weight loss, decay percentage, accumulation of T.S.S and sugar by diminishing the rate of respiration and metabolism (Arpit et al. 2017 and laura et al. 2008).

(Udomlak et al. 2008) reported that $400 \mathrm{mg} / \mathrm{ml}$ of clove oil inhibited the growth of 6 fungi on table grape planted in vitro, which caused the postharvest decay of grapes. Similar result were found on apple (Chanel et al. 2015) on citrus (Xingfeng, 2015, Tehmina and Nosheen 2012).

There for the aim of the present study was to investigate the effect of edible coating of Roomy Red grapes by chitosan and clove oil on weight loss and decay percentages of fruits during cold storage.

\section{Materials and Methods}

This study was conducted during two successive seasons of 2015 and 2016 on Red Roomy Grapes grown in the orchard of pomology Department, Faculty of Agriculture, Assiut University, to evaluate the effect of emulsifying fruits with some natural products on physical and chemical properties under cold storage.

At the harvest date many of clusters were collected and selected for uniformity of size and shape and absence of visible defects and were directly transferred to the laboratory of pomology department, Faculty of Agriculture, Assiut University.

The collected clusters were divided into three similar groups. Each group (consisted of 18 clusters) was subjected to one of the following treatments:

1- Control (distilled water)

2- Chitosan 2\%

3- Clove oil 3\%

The clusters of all treatments were dipped for 60 second in the solution of each treatment, and air dried and then stored at $0 \pm 2^{\circ} \mathrm{C}$.

\section{Chitosan preparation:}

Stock solution $(2 \%, w / v)$ of chitosan, was prepared by dissolving purified chitosan (low molecular weight 
chitosan was purchased from Sigma Chemical Co.) in $0.5 \%$ (v/v) glacial acetic acid under continuous stirring, and the $\mathrm{pH}$ was adjusted to 5.6 using $1 \mathrm{~N} \mathrm{NaOH}$. The stock solution was sterilized at $121^{\circ} \mathrm{C}$ for $20 \mathrm{~min}$., and then lower concentrations $(2 \%)$ were made by appropriate dilution with distillated water (Du et al. 1997).

\section{Clove oil preparation:}

$150 \mathrm{ml}$ of clove oil were dissolved in distilled water with tween 80 , and then brought to 5 liter of distilled water to obtain 3\% concentration of clove oil. (Ju et al. 2000).

The clusters of each treatment were placed carefully after drying in 8 ventilated polyethylene bags (3 clusters were subjected from each treatment to determine both weight loss and decay percentage). Each treatment were replicated 3 times (2clusters of each). The aforementioned treated cluster were stored under cold storage at $0 \pm 2{ }^{\circ} \mathrm{C}$ and 90 95\% R.H.

Clusters weight loss and decay percentages were determined periodically at weekly interval during the storage period at $0 \pm 2 \mathrm{C}$.

At weekly intervals three (3) clusters were randomly taken from each treatment to determine the weight loss and decay percentages of the berries.

\section{1- Fruit Weight Loss Percentage}

The initial weight of Red Roomy clusters was recorded for each treatment at weekly interval, and then fruit weight loss \% was calculated by weighing the same fruits at each interval until at the end of cold storage period

Using the following formula:

Fruit weight $\quad$ loss $\%=($ Initial weight - Weight at specific interval $) /($ Initial weight $) \times 100$

\section{2- Fruit Decay Percentage:}

The number decayed berries of each treatment were discarded and the number of such discarded berries related to the initial number of berries per each treatment was estimated and decay percentage was calculated.

\section{Statistical analysis:}

The obtained data were tabulated and subjected to the proper statistical analysis of variance according to the split plot design using LSD test for recognizing the significance differences among the various treatment means (Snedecor and Cochram. 1989).

Result and Discussion

1-Weight loss \%:

Table 1. The effect of chitosan and clove oil coating on the weight loss\% of Red Roomy grapes during cold storage in 2015 and 2016 season.

\begin{tabular}{|c|c|c|c|c|c|c|c|c|c|}
\hline \multicolumn{5}{|c|}{ Season 2015} & \multicolumn{5}{|c|}{ Season 2016} \\
\hline \multirow{2}{*}{ Period } & \multicolumn{3}{|c|}{ Treatments } & \multirow{2}{*}{ Mean } & \multirow{2}{*}{ Period } & \multicolumn{2}{|c|}{ Treatments } & \multirow[b]{2}{*}{ Clove oil } & \multirow{2}{*}{ Mean } \\
\hline & control & Chitosan & Clove oil & & & control & chitosan & & \\
\hline 0 week & 0.00 & 0.00 & 0.00 & 0.00 & 0 week & 0.00 & 0.00 & 0.00 & 0.00 \\
\hline 1week & 4.00 & 7.33 & 7.83 & 6.39 & 1week & 13.67 & 3.33 & 4.00 & 7 \\
\hline 2week & 10.33 & 11.00 & 13.50 & 11.61 & 2week & 18.00 & 8.67 & 9.50 & 12.06 \\
\hline 3week & 18.33 & 15.50 & 19.83 & 17.89 & 3week & 25.83 & 11.00 & 11.00 & 15.94 \\
\hline 4week & 25.00 & 19.00 & 25.33 & 23.11 & 4week & 29.00 & 15.83 & 18.53 & 21.12 \\
\hline 5week & 41.00 & 23.00 & 30.67 & 31.56 & 5week & - & 21.83 & 18.83 & 20.33 \\
\hline 6week & - & 27.67 & 35.00 & 31.34 & 6week & - & 24.00 & - & 24.00 \\
\hline \multicolumn{3}{|c|}{ L.S.D0.05A $($ treatment $)=$} & \multicolumn{2}{|l|}{9.77} & \multicolumn{3}{|c|}{ L.S.D0.05A $($ treatment $)=$} & \multicolumn{2}{|l|}{1.99} \\
\hline \multicolumn{3}{|c|}{ L.S.D0.05B(period) $=$} & \multicolumn{2}{|l|}{3.17} & \multicolumn{3}{|c|}{ L.S.D0.05B(period $)=$} & \multicolumn{2}{|l|}{1.31} \\
\hline \multicolumn{3}{|c|}{ L.S.D $0.05 \mathrm{AB}=$} & \multicolumn{2}{|l|}{5.49} & \multicolumn{3}{|c|}{ L.S.D $0.05 \mathrm{AB}=$} & \multicolumn{2}{|l|}{2.27} \\
\hline
\end{tabular}


The effect of chitosan and clove oil coating of Red Roomy grapes under cold storage on weight loss $\%$ are presented in Table (1):

In general the obtained result took approximately the same trend during both experimental seasons concerning the weight loss percentage.

It is also clear to notice that the weight $10 \mathrm{ss} \%$ significantly increased with the progress of storage period during 2015 and 2016 seasons by all applied treatments. Moreover the maximum values of weight loss $\%$ were recorded at end of storage period for all treatments.

The obtained result showed also that both of chitosan and clove oil coating significantly decreased the percentage of weight loss as compared with untreated grapes (control) during both tested seasons.
In addition the highest values of weight loss \% were found in the untreated (control) grapes at the end of storage period $(41.00 \%$ after 5 weeks of storage during the first season and $29.00 \%$ after 4 weeks during the second one). On the other hand, the lowest values of weight loss \% were recorded in the grapes coated with chitosan (27.67\% after 6 weeks of storage) during the first season, while clove oil treatment gave the lowest values of weight loss \% (18.83\% after 5 weeks of storage) during the second season 2016.

The obtained result were agreement with those found by (Meng X. et al. (2008, Shiri et al. (2013) and Al-Qurash and Awad (2015) Valero et al. (2006) in grapes and $\mathrm{El}$ ghaouth et al. (1991), Donglin and Quantick (2004), Hernandez-Munoz et al. (2008) and Petriccion et al. (2015) Baiea and El-Badawy. (2013) in other fruits.

Table 2. The effect of chitosan and clove oil coating on the decay\% of Red Roomy grapes during cold storage in 2015 and 2016 season.

\begin{tabular}{|c|c|c|c|c|c|c|c|c|c|}
\hline \multicolumn{5}{|c|}{ Season 2015} & \multicolumn{5}{|c|}{ Season 2016} \\
\hline \multirow{2}{*}{ Period } & \multicolumn{3}{|c|}{ Treatments } & \multirow{2}{*}{ Mean } & \multirow{2}{*}{ Period } & \multicolumn{3}{|c|}{ Treatments } & \multirow{2}{*}{ Mean } \\
\hline & control & Chitosan & Clove oil & & & Control & Chitosan & Clove oil & \\
\hline 0 week & 0.00 & 0.00 & 0.00 & 0.00 & 0 week & 0.00 & 0.00 & 0.00 & 0.00 \\
\hline 1week & 8.67 & 4.00 & 9.50 & 7.39 & 1week & 3.67 & 0.00 & 1.00 & 2.34 \\
\hline 2week & 17.17 & 7.65 & 13.00 & 12.61 & 2week & 12.67 & 0.00 & 2.00 & 7.36 \\
\hline 3week & 29.83 & 9.67 & 17.67 & 19.06 & 3week & 32.00 & 0.00 & 2.67 & 17.34 \\
\hline 4week & 42.67 & 10.33 & 26.00 & 26.33 & 4week & 58.00 & 4.67 & 14.67 & 25.78 \\
\hline 5week & 52.00 & 17.33 & 34.50 & 34.61 & 5week & - & 18.33 & 52.67 & 35.50 \\
\hline 6week & - & 46.33 & 48.67 & 47.50 & 6week & - & 55.00 & - & 55.00 \\
\hline \multicolumn{3}{|c|}{ L.S.D0.05A $($ treatment $)=$} & \multicolumn{2}{|c|}{8.39} & \multicolumn{3}{|c|}{ L.S.D0.05A (treatment $)=$} & \multicolumn{2}{|c|}{2.27} \\
\hline \multicolumn{3}{|c|}{ L.S.D0.05B (period $)=$} & \multicolumn{2}{|c|}{3.23} & \multicolumn{3}{|c|}{ L.S.D0.05B $($ period $)=$} & \multicolumn{2}{|c|}{1.68} \\
\hline \multicolumn{3}{|c|}{ L.S.D $0.05 \mathrm{AB}=$} & \multicolumn{2}{|c|}{5.59} & \multicolumn{3}{|c|}{ L.S.D $0.05 \mathrm{AB}=$} & \multicolumn{2}{|c|}{2.91} \\
\hline
\end{tabular}




\section{2-Decay \%:}

Data in Table (2) showed the effect of chitosan and clove oil coating on the percentage of decay in Red Roomy grapes during cold storage in 2015 and 2016 seasons.

Generally similar tendency was observed concerning decay \% during both tested seasons. The obtained result showed that the percentage of decay gradually and significantly increased by the prolonging the storage period and reached its maximum values at the end this period for all treatments during both 2015 and 2016 seasons.

Concerning the effect of chitosan and clove oil coating on the percentage of decay, it is clear to observe that, both treatments significantly decreased the decay $\%$ of grapes comparing with untreated fruits (control) during both investigated seasons. So the highest values of decay percentage were recorded in the untreated grapes (control) after 5 weeks of cold storage $(52.00 \%)$ during first season and (58.00\%) after 4 weeks of storage in the second season 2016. Moreover the lowest values of decay $\%$ were found in the coated grapes with chitosan $(46.33 \%)$ after 6 weeks of storage in the first season 2015, while the coated grapes with clove oil had the lowest value of decay $\%(52.67 \%)$ after 5 weeks of storage during the second season 2016.

The obtained results are in the line of those reported by Romanazzi. et al. (2002), Xu et al. (2007), Gao et al. (2013), Oliveira et al. (2014) and Udomlak et al. (2008) in grapes and Yueming et al. (2005), Jia et al. (2007), El-Badawy and El-Salhy
(2011) and Baiea and El-Badawy. (2013) in other fruits.

\section{References}

Al-Qurashi, A. D. and Awad M.A. (2015). Postharvest chitosan treatment affects quality, antioxidant capacity, antioxidant compounds and enzymes activities of 'ElBayadi' table grapes after storage. Scientia Horticulturae. 197:392398.

Anastasiadi, M., H. Pratsinis, D. K., A. L. Skaltsounis, Haroutounian S.A. (2010). Bioactive non-coloured polyphenols content of grapes, wines and vinification byproducts: Evaluation of the antioxidant activities of their extracts. Food Research Internationa. (43) 805-813.

Arpit, V. J., Nilanjana S. B., Pinal B. V. and Ramana Rao T.V.(2017). Gum ghatti based edible coating emulsion an additive of clove oil improves the storage life and maintains the quality of papaya (Carica papaya L., cv. Madhubindu). Int. J. Curr. Microbiol. App. Sci. 6(5):160-174.

Baiea, M.H.M. and El-Badawy H.E.M. (2013). Response of Washington navel orange to thyme and clove oils as natural postharvest treatments under cold storage conditions. Journal of Applied Sciences Research, 9(7): 4335-4344.

Baldwin, E.A., Niesperos, M.O., Shaw, P.E. and Burns, J.K. (1995). Effect of coating and prolonged storage condition on fresh orang flavor volatiles, degrees brix and acscorbic acid levels. Journal of Agricultural and Food Chemistry 43 (5): 1321-1331.

Chanel, D., Cheryl L. Lennox and Vries F.A. (2015). In vivo application of garlic extracts in combination with clove oil to prevent postharvest decay caused by Botrytis cinerea, Penicilliumexpansum and Neofabraea alba on apples. Postharvest 
Biology and Technology 99 8892.

Chitarra, M.I.F., Chitarra A.B. (2005). Postharvest of fruits and vegetable: physiology and handling. $2^{\text {nd }} \mathrm{ed}$. UFLA.Lavras. 785.

Dividson, P. M., Grizer F. J. and Taylor T. M. (2013). Naturally occurring antimicrobial for minimally processed food. Annual Review in food science and technology, 4:163190.

Donglin, Z. and Quantick P.C. (2004). Effects of chitosan coating on enzymatic browning and decay during postharvest of berries storage of litchi (Litchi chinensisSonn.) fruit. Postharvest Biology and Technology 12 195-202.

Du, J. H. Gemma and Iwahori S. (1997). Effects of Chitosan Coating on the Storage of Peach, Japanese Pear, and Kiwifruit. J. Japan. Soc. Hort. Sci. 6615-22.

El Ghaouth A., J. Arul and palm P. R.(1991). Use of chitosan coating to reduce water loss and maintain quality of cucumber and bell pepper. Journal of Food Processing and Preservation (15) 359-368.

El-Badawy H.E.M. and El-Salhy F.T.A. (2011). Physical and chemical properties of Canino Apricot fruits during cold storage as influenced by Somepost-harvest treatments. Australian Journal of Basic and Applied Sciences, 5(9): 537-548.

EPA, (1995). poly-D-glucosamine (chitosan), exemption from the requirement of a tolerance U.S. Environmental Protection Agency, Federal Register 60: 19523-19524.

Gao, P. Sh., Z. Z. Qiang and. Ping Z (2013). Effects of chitosan-glucose complex coating on postharvest quality and shelf life of table grapes. Carbohydrate Polymers. 95(1):371-378.

Gatto, M.A., A. Ippolito, V. Linsalata, N.A. Cascarano, Franco N., S. Vanadiaa, Venere D.D. (2011). Activity of extracts from wild edible herbs against postharvest fungal diseases of fruit and vegetables. Postharvest Biology and Technology $61,72-82$.

Hernandez-Munoz, P., E. Almenar, V. D. Valle, D. Velez and Gavara R. (2008). Effect of chitosan coating combined with postharvest calcium treatment on strawberry (Fragaria $\times$ ananassa) quality during refrigerated storage. Food Chemistry (110) 428-435.

Jia, L., Sh. Tian, X. Menga and Xua Y. (2007). Effects of chitosan on control of postharvest diseases and physiological responses of tomato fruit. Postharvest Biology and Technology (44) 300-306.

Ju, A.T., J.H. Warcup, W.M. Wright and Pugh G.J.F.(2000). The effect of fungicide on certain chemical and microbial of soil. Soil Biol. Biochem., 6(4): 263-267.

Kumar, S. and Bhatnagar T. (2014). Studies to enhance the shelf life of fruits using Aloe verabased herbal coatings. A review.Int $\mathrm{J}$ Agric Food Sci Technol. 5: 211-218.

Laura, L. B.-N., Silvia B.-B., Hilda E. F.-M.and Abel R. E.(2008). Efficacy of essential oils on the Conidial Germination, Growth of Colletorichumglowosporioides (Penz.) penz. andSacc and control of postharvest diseases in Papaya (Carica papaya L.). Plant Pathology Journal. 1812-5387.

Meng, X. H., L. Boqiang, L. Jia and Shiping T. (2008). Physiological responses and quality attributes of table grape fruit to chitosan preharvest spray and postharvest coating during storage. Food Chemistry. 106(2):501-508.

Oliveira, C. E. V., M. Magnani; C. V. Sales, A. L. S.Pontes, G. M. Campos-Takaki, T. C. M. Stamford, and Souza E. L. (2014). Effects of post-harvest treatment using chitosan from Mucorcircinelloides on fungal pathogenicity and quality of 
table grapes during storage. Food Microbiology. (44)211-219.

Park, H.J. (1999). Development of advanced edible coating for fruits. Trend Food Sci. Technol. 10, 254290.

Petracek, P.D., Dou H. and Pao S. (1998). The influence of applied waxes on postharvest physiological behavior and pitting of grapefruit. Postharvest Biology and Technology 14, 99-106.

Petriccione, M., F. Mastrobuoni, M. S. Pasquariello, L. Zampella, E. Nobis, G. Capriolo and Scortichini M.(2015). Effect of Chitosan Coating on the Postharvest Quality and Antioxidant Enzyme System Response of Strawberry Fruit during Cold Storage. Foods (4) 501-523.

Romanazzi, G.; F. Nigro; A. Ippolito; D. Venere and Salerno M. (2002). Effects of pre- and postharvest chitosan treatments to control storage grey mold of table grapes. Journal of Food Science. 67(5):1862-1867. 40.

Sandford, P.A. and Hutchings G.P. (1986). Chitosan a natural, cationic biopolymer: commercial application .Elsevier science publisher B.V. The Netherlands.363-376.

Shiri, M. A., M. Ghasemnezhad, D. Bakhshi and Sarikhani H. (2013). Effect of postharvest putrescine application and chitosan coating on maintaining quality of table grape v. "Shahroudi" during long-term storage. Journal of Food Processing and Preservation. 37(5):9991007.

Snedecor, G.W. and Cochran W.G. (1989). Statistical Methods, Eighth Edition, Iowa State University Press.

Tehmina, A. and Akhtar N.(2012). Antifungal Activity of Essential Oils
Extracted From Clove, Cumin and Cinnamon Against Blue Mold Disease on Citrus fruit. Intrnational Conference on applied life sciences Turkey. 10-12.

Terry, L. A. and Joyce D.C. (2004). Elicitors of induced disease resistance in postharvest horticultural crops: a brief review. Postharvest Biology and Technology.

Udomlak, S., V. Haruthaithanasan, W. C.U. Dilokkunanant and Suppakul P.(2008). Antifungal Activity of Clove and Cinnamon Oil and Their Synergistic Against Postharvest Decay Fungi of Grape in vitro. Kasetsart J. (Nat. Sci.) 42: 169 174.

Valero, D., J.M. Valverde, D. Mart'inezRomero, F. Guill'en, S. Castillo and Serrano M. (2006). The combination of modified atmosphere packaging with eugenol or thymol to maintain quality, safety and functional properties of table grapes. Postharvest Biology and Technology (41) 317-327.

Xingfeng, Sh., B. Cao, F.Xu, S.Xie, D. Yu and Wang H. (2015). Effect of postharvest application of chitosan combined with clove oil against citrus green mold. Postharvest Biology and Technology 99 37-43.

$\mathrm{Xu}$ W.-T., K.-L.Huang, F. Guo, W.Qu, J.-J.Yang, Z.-H.Liang and. Luo Y.B. (2007). Postharvest grapefruit seed extract and chitosan treatments of table grapes to control Botrytis cinerea. Postharvest Biology and Technology 46(1):86-94.

Yueming, J., J. Li and Jiang W. (2005). Effects of chitosan coating on shelf life of cold-stored litchi fruit at ambient temperature. Food Science and Technology 38 (7) 757-761. 
تأثير الثيتوسان وزيت القرنفل علي بعض الصفات الطبيعية والكيماوية لثمار العنب الرومي

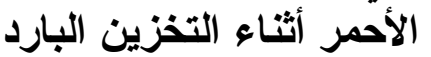

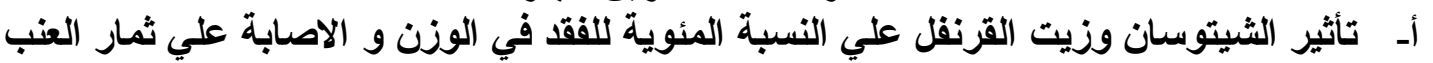

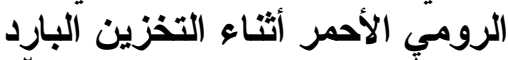

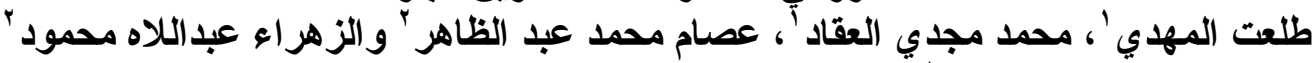

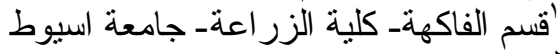

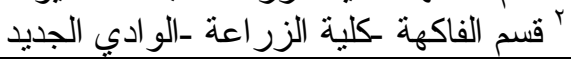

اجريت هذه التجربة في مععل قسم الفاكهة بكلية الزر اعة جامعة أسيوط علي ثمار العنب

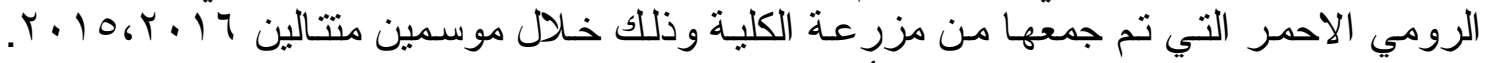

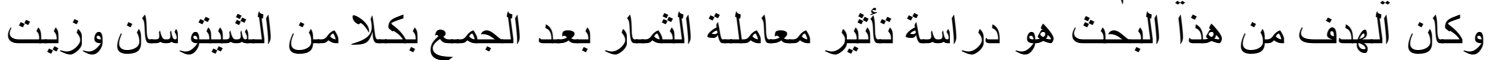

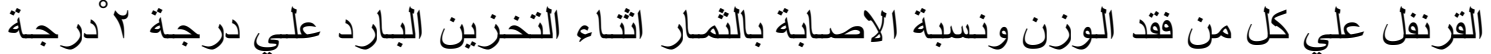

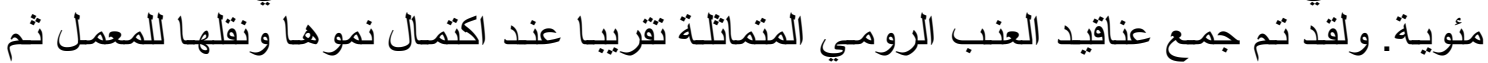

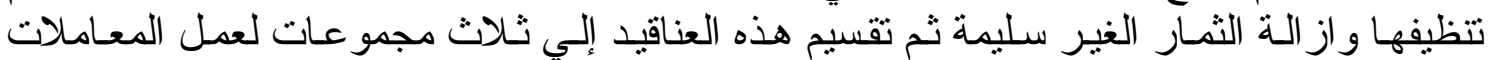

$$
\text { r - النقع لـدة دقيقة في الماء المقطر (الكنترول). }
$$

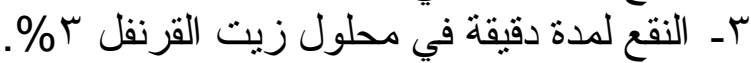

تم وضع عناقيد كل مجمو عة بعد جفاف الثمار في اكياس بولئ بولي ايثيلين منقبة تم وضعها في الثناجة علي درجة حر ارة ب درجة مئوية. تم قياس الفقد في وزن الثمار وكذلك نسبة الاصدابة بها اسبو عيا وكانت اهم النتائج المتحصل عليها كالاتي: - ماني

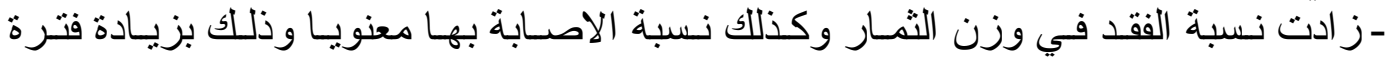

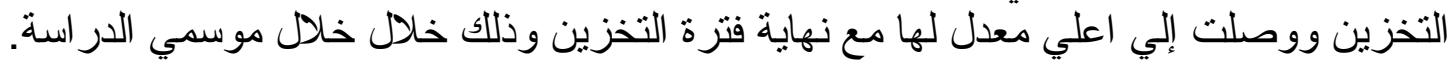

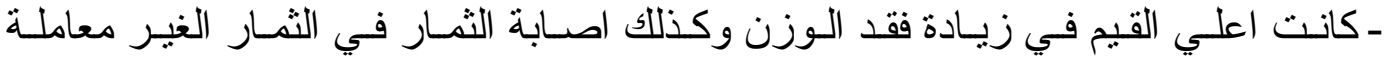

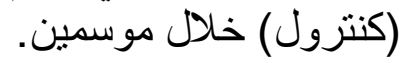

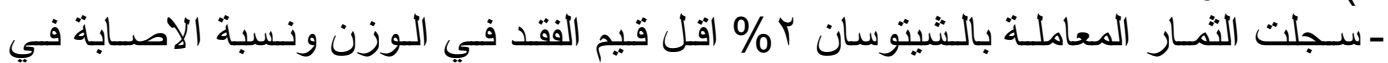

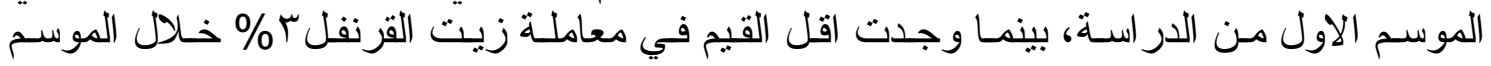

